\title{
Inventory of potential vectors of trypanosoma and infection rate of the Tsetse fly in the National Park of Ivindo, Gabon.
}

\author{
Mbang Nguema $\mathrm{OA}^{1,2,3}$, Mavoungou JF${ }^{1,3}$, Mawili-Mboumba $\mathrm{DP}^{2}$, Zinga Koumba $\mathrm{RC}^{1}$, \\ Bouyou-Akotet $\mathrm{MK}^{2}$, M’batchi B
}

1. Intitut de Recherche en Ecologie Tropicale (IRET), BP 13354, Libreville, Gabon.

2. Department of Parasitology-Mycology, Faculty of Medicine, Université des Sciences de la Santé, BP 4009, Libreville, Gabon.

3. Université des Sciences et Techniques de Masuku, BP 941, Franceville, Gabon.

\begin{abstract}
Background: Trypanosoma's vectors distribution is poorly investigated in Gabon, where Trypanosomiasis historical foci exist. Thus, an active detection of Trypanosoma sp transmission needs to be assessed.

Objectives: The present study aims to identify potential vectors of Trypanosoma sp and to evaluate the infection rate of the Tsetse fly in an area of Gabon.

Methods: An entomological survey was conducted in the National Park of Ivindo in May 2012 using Vavoua traps. All captured insects were identified. Tsetse were dissected and organs were microscopically observed to detect the presence of Trypanosoma sp.

Results: 247 biting flies known as vectors of Trypanosomiasis were caught including 189 tsetse flies, 32 Tabanid and 26 Stomoxys. Tsetse flies had the highest bulk densities per trap per day (ADT $=3$ tsetse / trap / day), while the lowest density was found among Stomoxys (ADT $=0.41$ Stomoxys / trap / day). The infection rate of flies was $6.3 \%$. Infectious organs were midguts and to a lesser extent salivary glands and proboscis.

Conclusion: The presence of Tsetse infected by Trypanosoma highlights an existing risk of trypanosomiasis infection in the National Park of Ivindo.

Keywords: Tsetse fly, Tabanids, vector, Stomoxys, biodiversity, trypanosomiasis.

DOI: http://dx.doi.org/10.4314/ahs.v15i3.9

Cite as: Mbang Nguema OA, Mavoungou JF, Mawili-Mboumba DP, Zinga Koumba RC, Bouyou-Akotet MK, M'batchi B. Inventory of potential vectors of trypanosoma and infection rate of tsetse in the National Park of Ivindo, Gabon. Afri Health Sci. 2015;15(3):762-7. doi: bttp:/ / dx.doi.org/10.4314/ahs.v15i3.9
\end{abstract}

\section{Introduction}

Human African Trypanosomiasis (HAT) or sleeping sickness threatens 70 million of people in sub-Saharan Africa ${ }^{1}$. Without adequate treatment, sleeping sickness is a fatal disease. However, less than $10 \%$ of at-risk populations are monitored. Since 2009, less than 10000 of HAT cases have been reported, but the World Health Organization (WHO) estimates that the number of infected persons is near of $20000^{1}$. HAT is endemic in 35 countries of the African region with variable levels and

\footnotetext{
Corresponding author:

Bouyou-Akotet MK

Department of Parasitology-Mycology,

Faculty of Medicine, Université

des Sciences de la Santé,

BP 4009, Libreville, Gabon.

Email address: mariellebouyou@gmail.com
}

is located in more than 250 active foci mainly in Angola, Democratic Republic of Congo and Sudan ${ }^{2,3}$.

In Central Africa, trypanosomiasis is endemic in all ecological features (forest, savannah, mangrove, river valleys, islands, etc. $)^{4}$. In Gabon, a historic landmark of the HAT in Central Africa, the disease was endemic in seven of the nine provinces during the last century ${ }^{5}$. Recently new cases from the provinces of the Estuaire and Ogooué Maritime have been reported (reports Programme National de Lutte contre la Trypanosomose Humaine Africaine). The Komo-Mondah, inside Estuaire, is the most active focus of HAT in Gabon with an average of 20 cases per year ${ }^{6}$. In this focus, Trypanosoma $s p$, transmitted by tsetse flies and mechanically by tabanids and stable flies, have been found ${ }^{7}$; notably Trypanosoma brucei gambiense, a human Trypanosoma and Trypanosoma congolense and Trypanosoma vivax, cattle parasites ${ }^{6,8}$. Nevertheless, other existing old foci of the disease are not monitored since several years; thus the proportion of persons at risk of acquiring the disease is presumably underestimated in the country. 
In the region of Ogooue Ivindo, in the east of country, old foci were mainly located along rivers and tributaries 9 . Previous work on the abundance and distribution of blood sucking Diptera revealed a high density of stable flies, tabanids and tsetse flies in the Baï located near the National Park of Ivindo ${ }^{10}$.The aim of the study was to determine the density of Trypanosoma vectors and to assess the infection rate of the tsetse fly, in the National Park of Ivindo in Gabon, fifteen years after the last survey.

\section{Methods:}

\section{Study site:}

The study was conducted in May 2012 at Ipassa, situated in the NPI, in the region of the Ogooué-Ivindo, in the North-Eastern part of Gabon. It is a forest area located at $632 \mathrm{~km}$ from Libreville, the capital city of Gabon ${ }^{11}$. The National Park of Ivindo has a wide biodiversity and its ecology is already described ${ }^{11-12}$. The climate is equatorial, characterized by an alternation of two dry (mid-December to mid-March and mid-June and mid-September) and two rainy seasons (mid-March to mid-June and mid-September to mid-December). The average annual rainfall is about $1600-1800 \mathrm{~mm}$. The mean temperature is about $24^{\circ} \mathrm{C}$ with a minimum of $21.7^{\circ} \mathrm{C}$ in July and a maximum of $25^{\circ} \mathrm{C}$ in April. The vegetation is composed by primary, secondary forests, and flood plain forests. The fauna is rich and diverse ${ }^{12}$. The main activities of the inhabitants are fishing, hunting and agriculture.

\section{Entomological survey:}

Sessions fly trapping were conducted during the long rainy season with Vavoua traps ${ }^{13}$. A network of nine traps was set up during seven days. All traps were placed in the forest environment along the Ivindo river, 500 $\mathrm{m}$ away from each other. Each trap site was cleared to ensure reasonable visibility of the trap and was activated before 7:00.am and withdrawn after 5:00.pm. When the traps are controlled, each capture cage, contained in the trap, is recovered, numbered and dated; and during the day sent to the laboratory, at the station of the Institute for Research in Tropical Ecology Research located at $12 \mathrm{~km}$ from the city of Makokou.

\section{Fly identification and Trypanosoma detection in} tsetse:

The fly's species identification was performed in the laboratory. Morphological discrimination between dif- ferent fly's taxa (Glossina, Stomoxys, Tabanids) was made according to the species identification keys: the Oldroyd key for Tabanidae group, Pollock and Brunhes for tsetse flies group and the Zumpt key for the stable flies group $(\text { Stomoxys })^{14,15,16,17}$. All observations and dissections were performed under a magnifying glass.

After sorting, identification and counting, tsetse flies were dissected (within $24 \mathrm{~h}$ following the capture) into a drop of sterile $0.9 \%$ saline water. Midgut, proboscis and salivary glands were then examined with a light microscope at a 400x magnification for the detection of Trypanosoma in the trypomastigotes procyclical form. Teneral flies were identified by the residual bag of the larval stage in the midgut ${ }^{18}$. Organs, both infected and uninfected were transferred separately into a microfuge tubes containing $50 \mu \mathrm{l}$ of $70 \%$ ethanol and stored in $-20^{\circ} \mathrm{C}$ for further molecular analysis.

\section{Data analysis}

Data were recorded and analyzed using Excel.

The abundance of each flies species was defined by the apparent density per trap and per day (ADT) as follows:

$$
\mathrm{ADT}=\frac{\text { Number of flies captured }}{\text { Number of traps } \mathrm{x} \text { number of days of capture }}
$$

The sex-ratio was determined as follows: Number of males/ Number of females

The fly infection rate was calculated using the following formula:

Infection rate $=$ (Number of infected flies / Total Number of dissected flies) x100

The Trypanosoma risk index $=($ ADT $\mathrm{x}$ infection rates $)$ was also calculated.

The Margalef diversity index was calculated to assess the diversity of the fly species in the study area. This index is calculated using the following formula: $\mathrm{D}=(\mathrm{S}-1) /$ $\log \mathrm{N}$, where "S" is the number of species and "N" the total number of individuals collected ${ }^{19}$.

\section{Results:}

A total of 247 biting flies, belonging to the following families Tabanidae, Muscidae and Stomoxydae,were collected. They were distributed into 5 genus: Glossina $(\mathrm{n}=189)$,Stomoxys $(\mathrm{n}=26)$, Chrysops $(\mathrm{n}=23)$, Tabanus $(\mathrm{n}=$ 7) and Ancala $(\mathrm{n}=2)$. The apparent density per trap and per day (ADT) was $3 \mathrm{G} / \mathrm{t} / \mathrm{d}$ for Glossina, $0.4 \mathrm{~S} / \mathrm{t} / \mathrm{d}$ for Stomoxys and $0.5 \mathrm{~T} / \mathrm{t} / \mathrm{d}$ for Tabanid. 
Species identification:

Among tsetse flies, the predominant species was Glossina palpalis palpalis ( $\mathrm{n}=114,60.3 \%$ ) (Table 1). G. fusca congolensis, G. nashi, G. tachinö̈des, G. tabaniformis and $G$. frezili were also identified in the study site (table 1). In this group the Margalef index was 2.2. Teneral flies ( $\mathrm{n}=$ 9) were collected in the biotope including Glossina palpalis palpalis $(\mathrm{n}=4)$, Glossina fusca congolensis $(\mathrm{n}=2)$, Glossina nashi $(\mathrm{n}=2)$ and Glossina frezili species $(\mathrm{n}=1)$.
Among Tabanidae ( $\mathrm{n}=32)$, Tabanus, Chrysops and Ancala genus were determined.

The most abundant species identified was Chrysops silaceus $(53 \% ; \mathrm{n}=17)$. Chrysops dimidiata $(\mathrm{n}=6)$, Tabanus sp $(\mathrm{n}=5)$, Tabanus taeniola $(\mathrm{n}=2)$, Ancala nilotica $(\mathrm{n}=1), A n$ calafasciata $(\mathrm{n}=1)$ were also found.The Margalef index was of 3.3.

Out of the four Stomoxys species found during the survey, Stomoxys inornatus $(73 \% ; \mathrm{n}=19)$ predominated although Stomoxys nigra nigra $(\mathrm{n}=3)$, Stomoxys indica $(\mathrm{n}=3)$ and Stomoxys omega $(\mathrm{n}=1)$ were also identified. Stomoxys Margalef index was of 2.1.

Table 1: abundance and infection rate of the tsetse fly

\begin{tabular}{lcccccc}
\hline Tsetse flies & \multicolumn{4}{c}{ Gender } & \multicolumn{2}{c}{ Infection rate } \\
\hline Species & $\mathrm{N}$ & $\%$ & Male, $\mathrm{n}$ & Female, $\mathrm{n}$ & Male, \%(n) & Female, \%(n) \\
\hline G. palpalis palpalis & 114 & 60.3 & 55 & 59 & $5.4(3)$ & $10.1(6)$ \\
G. fusca congolensis & 36 & 19.1 & 16 & 20 & $0.0(0)$ & $0.0(0)$ \\
G. nashi & 14 & 7.4 & 5 & 9 & $0.0(0)$ & $0.0(0)$ \\
G. tachnoïdes & 11 & 5.8 & 4 & 7 & $0.0(0)$ & $14.3(1)$ \\
G. tabaniformis & 7 & 3.7 & 3 & 4 & $33.3(1)$ & $25.0(1)$ \\
G. frezili & 7 & 3.7 & 5 & 2 & $0.0(0)$ & $0.0(0)$ \\
Total & $\mathbf{1 8 9}$ & $\mathbf{1 0 0}$ & $\mathbf{8 8}$ & $\mathbf{1 0 1}$ & $\mathbf{4 . 5}(\mathbf{4})$ & $\mathbf{7 . 9}(\mathbf{8})$ \\
\hline
\end{tabular}

Sex-ratio and rate of infection among Tsetse flies: The sex-ratio of the captured tsetse flies was 0.9 (Table 1). All tsetse flies were dissected. Among them, 12 were found infected out of which nine were G. palpalis palpalis, two G. tabaniformis and one G. tachinoides. The infection rate was of $6.6 \%(n=12 / 180)$ in the non teneral flies. The Trypanosoma risk index was of 0.19 . The sex ratio of infected flies was 0.5 . Females were more infected: $7.9 \%$ infected females $(\mathrm{n}=8 / 101)$ and $4.5 \%$ $(\mathrm{n}=4 / 88)$ infected males. The infection was detected in the midgut of all flies. In five tsetse flies, salivary glands and proboscis were additionally infected.

\section{Discussion:}

The control and the monitoring of HAT transmission in historical focus where the disease is considered eliminated are based on selective serological surveillance ${ }^{2}$. However, entomological surveys allowing the vectors and reservoir identification as well as the parasite detection are required to assess the local transmission of 
Trypanosoma sp. In the present study, investigations on Trypanosoma sp vectors distribution in an old focus of the National Park of Ivindo in Gabon showed a high prevalence of Tsetse flies, vectors of HAT, as well as stable flies and Tabanids among circulating flies. Stomoxys and Tabanids, potentials vectors of Trypanosoma sp, represented $10 \%$ and $3 \%$ of the whole flies collected, respectively.

Overall, 15 species of flies have been identified, except five from the Tabanidae family. Within each group, between four and six species were identified; comparable Margalef index was found between tsetse flies and stomoxes. In a previous study carried out in the area of Ogooué Ivindo, precisely along a transect in the Baï, 22 different species were detected during the rainy season; 14 Tabanids, five Glossina and three Stomoxys species ${ }^{20}$. The location of the study may influence the fly's species diversity. NPI and the Bai, which is at a distance of 160 $\mathrm{km}$, share the same fly species. Nevertheless, G.frezili, $G$ nashi S. indica, $A$. nilotica, $A$ fasciata and $C$. dimidiata were not found in the Baï during the rainy season. In this forest of Ogooué Ivindo, all environmental components such as temperature $\left(15^{\circ} \mathrm{C}-25^{\circ} \mathrm{C}\right)$, humidity and light are found for the ubiquitous distribution of the tsetse fly ${ }^{21}$.

The group of Tsetse flies, the single biological vectors of trypanosomiasis, was the most abundant in the park. Females were more frequently captured. Similar observations were previously reported and were related to the technique of capture ${ }^{22,23}$. It is suggested that Glossina females are more frequently captured by Vavoua trap, as observed in the present study ${ }^{22}$. Among the captured Tsetse flies, less than 5\% were teneral, that is a good indicator of tsetse reproduction sites; while none was found in a study carried out in Ivory Coast out of 269 flies examined during the rainy and dry seasons ${ }^{22}$.

The present study is the first performed after more than fifteen years to investigate the Glossina infection rate in the region of Ogooue Ivindo ${ }^{6}$. Identification of infected tsetse flies reveals the existence of a local transmission cycle of Trypanosoma sp at the NPI. Glossina palpalis palpalis, the main vector of human Trypanosomiasis, was the main fly species infected, mostly females as reported elsewhere $e^{21,8,24,25}$. The predominance of females among infected flies is probably due to the greater number of meals taken compared to male and to their longer life ${ }^{23}$. Trypanosoma $s p$ was specifically detected in the midgut and secondarily (or not) in salivary glands, as reported by others ${ }^{26,27}$.

The infection rate in the present study, although determined after microscopic examination, is higher than the rate found by PCR, a highly sensitive method, in a neighboring country, Equatorial Guinea, precisely at Campo Rio (3.2\%), suggesting the detection of a likely higher prevalence of infected flies if molecular tools were used in the present survey ${ }^{27}$. Nevertheless, it is lower compared to the rate reported in the suburban area of Libreville $(9.3 \%)$ and in various areas from Ivory Coast ranging from 20 to $28 \% 0^{27,28}$.

Between 2000 and 2009, 328 HAT cases have been reported in Gabon, among them, six were European cases whom one was exposed in a rural forest area ${ }^{3}$, 29,30,31. Moreover, data from epidemiological and entomological surveys carried out in Gabon, specifically, in the province of the Estuary and more recently, the Ogooue-Maritime region, showed the transmission of the disease in these areas ${ }^{5,6,24,25}$. The present findings highlight the need of identification of species of trypanosomes endemic in the NPI and of the case detection by an active screening of the population at risk in the NPI and in the surrounding areas along the river.

\section{Limitation}

The main limitation of the study was the lack of Trypanosoma species molecular identification. Taking into account that the development of many insects may present some peak of abundances depending on climatic factors, the differences of abundance observed between the detected insect families should be taken with caution ${ }^{32}$.

\section{Conclusion}

Different species of blood-sucking flies, potential vectors of trypanosomiasis, have been identified at Ogooue Ivindo. The presence of infected tsetse flies in this locality, former HAT foci, and especially in the Ivindo reserve underlines the existence of a Trypanosoma sp transmission risk in this area. Although, a contact between tsetse flies and human must be demonstrated and the human Trypanosoma sp identified to confirm the local transmission of HAT, Ivindo is an old focus and the presence of infected flies highlight the importance of Trypanosoma species identification in this area. 


\section{Competing interests}

The authors declare that they have no competing interests.

\section{References}

1. WHO: African trypanosomiasis (Sleeping sickness) WHO, Aide-mémoire. ${ }^{\circ} 259$, Mars 2014.

2. épin J, Meda AH. The epidemiology and control of human African trypanosomiasis, Advances in Parasitology 2001, 49, 71-132.

3. Simarro P.P, Cecchi G, Paone M et al. The Atlas of Human African Trypanosomiasis: acontribution to global mapping of neglected tropical diseases. Int J Health Geigr 2010, 9: 57.

4. Louis FJ. Les raisons techniques de la réémergence de la maladie du sommeil. Méd Trop 2001, 61:425- 431.

5. Georgelin. Maladies endémiques et endémo-épidémiques constatées au Gabon pendant l'année 1921-1922. Ann Med Pharm Colon 1923, 21 : 209-15.

6. Kohagne L, Gounoue R, Mengue P et al. Enquête entomologique dans le foyer historique de Trypano $\urcorner$ somose Humaine Africaine de Bendje (Gabon). Parasite 2011, $18:$ 303-309.

7. Kohagne Tongue L. Etude épidémiologique et entomologique de la Trypanosomiase Humaine Africaine dans trois foyers endémiques en Afriquecentrale. Thèse de Doctorat. Université de Yaoundé I, 2012.

8. Kohagne L, Mengue P, Mimpfoundi R, Louis JF. Entomological patterns in the human African trypanosomiasis focus of Komo Mondah, Gabon. Afr Health Sci 2010, 10 (4): 342-348.

9. Martin G, Roubaud E, Le bœuf A. La maladie du sommeil au Congo français. Masson éd Paris 1909, 717p. 10. Zinga Koumba R.C, Bouyer J, Mavoungou JF et al. Evaluation de la diversité des diptères hématophages dans une clairière marécageuse du Gabon à l'aide des pièges Vavoua et Nzi. Revue Elev. Méd. vét. Pays trop 2013, 66 (3) : 91-96.

11. C. Wilks. La conservation des écosystèmes forestiers du Gabon. Programme pour les forêts tropicales, UINC/CCE, 1990, 125pp.

12. Iret, Ecotrop, /Unesco. Une station de recherche en écologie forestière tropicale. Makokou, Gabon, 1987, $52 \mathrm{pp}$.

13. Lavessière C, Grébaut P. The trapping of tsetse flies (Diptera: Glossinidae). Improvement of a model: the Vavoua trap. Tropl Med Parasitol 1990 ,41 (2): 185-192.

14. Oldroyd H.M.A. The horse flies (Diptera: Tabanidae) of the Ethiopian region. Subfamilies, Chrysopinae,
Scepsidinae and Pangonunae, a revised classification. Bristish Museum (Natural History), London, Tome III. 1957, 489 p.

15. Pollock JN. Manuel de lutte contre la mouche Tsétsé. Volume 1: Biologie, systématique et répartition des tsé-tsé. FAO, Rome 1992, 310 pp.

16. Brunhes J, Cuisance D, Geoffroy B, Hervy JP. Les glossines ou mouches tsé-tsé. Logiciel d'identification et d'enseignement. Editions ORSTOM, Montpellier, France. 1998.

17. Zumpt F. The Stomoxyinae biting flies of the world. Taxonomy, biology, economic Importance and control measures. Gustav Fischer Verlag, Stuttgart 1973, 175 p.

18. Laveissière C. Détermination de l'âge des glossines ténérales. Cah ORSTOM sér Ent Méd Parasitol 1975, 13: 3-11.

19. Legendre L, Legendre P. Écologie numérique. Le traitement multiple des données écologiques. Masson, Paris et les Presses de l'Université du Québec, Montréal 1979, 197 p.

20. Zinga Koumba CR, Mbang Nguema OA, Mavoungou FJ, Obame Ondo KP. Ecodistribution des tabanides, glossines et stomoxes le long d'un transect foret primaire -village au Gabon. Int. J. Biol. Chem. Sci. 2014, 5(4):1712-1726.

21. Solano P, Bouyer J, Itard J, Cuisance D. The cyclical vectors of trypanosome. Infectious and parasitic diseases of livestock 2010, 13:155-183.

22. Allou K, Acapovi-Yao G, Kaba D, Bosson-Vanga $\mathrm{H}$, Solano P, \& N'goran KE. Chorologie et infection par les trypanosomes de Glossina palpalis palpalis dans la foret du Banco et ses reliques, Abidjan (Côte d' Ivoire). Parasite 2009, 16, 000-000.

23. Kohagne L, Mavoungou JF, Fako Hendji GC, Pamba $\mathrm{R}, \mathrm{Mbatchi} \mathrm{B}$. Is there a suburban sleeping sickness in Libreville? African Health Sciences 2013, 13(2): 266 269.

24. Kohagne L, Mengue P, Mimpfoundi R, Louis FJ. Régime alimentaire des glossines et diversité des espèces de trypanosomes humaines africaine au Gabon. Bulletin de la société pathologique Exotique 2010 a, 103 : 264-271.

25. Cordon-Obras C, Garcia-Estebanez C, Ndong-Mabale N, Abaga S, Ndongo-Asumu P, A. Benito, J. Cano. Screening of Trypanosoma brucei gambiense in Domestic Livestock and Tsetse Flies from an Insular Endemic Focus (Luba, Equatorial Guinea). PLoS Negl Trop Dis 2010, 4(6): e704.

26. Kazadi JM., Losson B, Kageruka B. Compétence vectorielle des mouches non ténérales de Glossina mor- 
sitans morsitans (Souche Mali) infectées par Trypanosoma (nannomonas) congolense IL 1180. Bull Soc Pathol Exot 2000, 93 (2), 125-128.

27. Jamonneau V, Ravel S, Koffi M, KABA D, Zeze DG, N'dril. Mixed trypanosome infections in tsetse and pigs in their epidemiological significance in a sleeping sickness focus in Cote d'Ivoire. Parasitology 2004, 129, 693-702.

28. Gomes J, Leão C, Ferreira F, Afonso M, et al. Molecular identification of T. brucei s.l. in tsetse flies after long-term capture in field traps. I Infect Dev Ctries 2009, 3(9):735-738.

29. Gautret P, Clerinx J, Caumes E et al. Imported hu- man African trypanosomiasis in Europe, 2005-2009. EUROSURVEILLANCE 2009, Vol. 14 • Issue 36.

30. Simarro PP, Franco J, Diarra A, Postigo JA, Jannin J. Update on field use of the available drugs for the chemotherapy of human African trypanosomiasis. Parasitology 2012, 139, 842-846.

31. Koko J, Ategbob SJ, Gahouma D, Engohan-Aloghe E, Moussavou A. Trypanosomose humaine africainerévélée par une fièvre prolongée: à propos de trois cas pédiatriques. Archives de Pédiatrie 2013, 20:871-873 PubMed .

32. Rodhain FS \& Perez C. Précis d'entomologie médicale et vétérinaire. Eds Maloine, Paris, France 1985. 